\title{
PENGARUH BEBAN TERHADAP STRES YANG DIALAMI KELUARGA DALAM MERAWAT PASIEN GANGGUAN JIWA
}

\author{
Fajar Rinawati ${ }^{1 *}$, Sucipto $^{2 *}$ \\ *Dosen Keperawatan Jiwa, Akademi Keperawatan Dharma Husada Kediri, \\ J1 Penanggungan No. 41 A Kediri, Jawa Timur \\ *email: ukhtifajr@yahoo.com
}

\begin{abstract}
Patients with mental disorders in community (a family) will have impact on the family, the environment, and the other, such as Puskesmas, Dinkes, and Goverment. The graetest impact is on the family, because they live together with the patient everyday. the main problem that arises in the family is the burden and stress in caring the patient. The purpose of this research is to see whether there is an influence of the burden on the stress of the family who caring the patient with mental disorder at home. The research design used is a quantitative design with cross sectional approach. The sample of this research is a family that caring the patient with mental disorder, with a sample zise of 30 respondens. The results showed that the burden significantly affects to the stress, with p-value 0.008. every family who caring the patients with mental disorder must have felt the burden, both the visible and the invisible. This burden will cause stress to the family, so need cooperation to the others, such as all family members, the environment, Puskesmas, Dinkes, and Goverment.
\end{abstract}

Keywords: effect, burden, stress, family, and mental disorder

\section{PENDAHULUAN}

ODGJ (orang dengan gangguan jiwa) merupakan sebutan bagi pasien yang mengalami gangguan jiwa. ODGJ menurut UU Kesehatan Nomor 18 tahun 2014 adalah orang yang mengalami gangguan dalam pikiran, perilaku, dan perasaan yang termanifestasi dalam bentuk sekumpulan gejala dan/atau perubahan perilaku bermakna, serta dapat menimbulkan penderitaan dan hambatan dalam menjalankan fungsi orang sebagai manusia. Dampak yang muncul dengan adanya ODGJ bukan hanya pada pasien, namun juga pada keluarga, masyarakat di sekitar, bahkan pemerintahan (Riskesdas, 2013). Orang yang paling merasakan dampak dengan adanya pasien gangguan jiwa adalah keluarga, karena keluarga merupakan orang yang tinggal dan merawat pasien (Stuart, 2013).

Jika salah satu anggota keluarga ada yang mengalami gangguan jiwa, maka keluarga akan merasa sedih, ikut merasakan sakit, kebingungan dalam merawat, malu menghadapi stigma yang ada di masyarakat, dan malu untuk bersosialisasi. Hal ini disebut dengan beban keluarga (Burland, 2002; Muhlbauer, 2008; Marshall et al, 2010; Stuart, 2013). Setiap beban atau masalah yang dihadapi merupakan suatu stressor yang akan menimbulkan stres.

Stres yang dihadapi keluarga dengan adanya pasien gangguan jiwa ditunjukkan dengan perubahan dalam waktu istirahat, perubahan nafsu makan, hilangnya ketertarikan dalam menjalani hiburan yang dulu menyenangkan, dan terganggu dalam melakukan ibadah. Oleh karena itu keluarga (terutama caregiver) perlu mendapatkan pertolongan untuk mencegah stres berlanjut, karena keluarga merupakan populasi yang berisiko mempunyai masalah kejiwaan (Stuart, 2013). 
Penelitian menunjukkan bahwa keluarga mempunyai level yang tinggi pada depresi, sangat sedikit menerima program peningkatan kesehatan, level yang rendah pada kesehatan psikologi, dan kurang kepuasan dalam pernikahan (Gerkensmeyer et al, 2008; Ghosh and Greenberg, 2009; Stuart, 2013).

Berdasarkan latar belakang di atas, peneliti tertarik meneliti tentang pengaruh beban terhadap stres yang dialami oleh keluarga dalam merawat pasien gangguan jiwa di Wilayah Kerja Puskesmas Balowerti dan Campurejo Kota Kediri.

\section{METODOLOGI}

Desain penelitian yang digunakan adalah penelitian kuantitatif dengan pendekatan cross sectional. Sampel yang digunakan adalah keluarga yang merawat pasien gangguan jiwa. Metode sampling yang digunakan adalah purposive sampling dengan beberapa kriteria inklusi. Jumlah sampel yang didapatkan adalah 30 responden. Waktu penelitian sekitar 5 bulan (April-September 2017). Tempat penelitian di Wilayah Kerja Puskesmas Balowerti dan Puskesmas Campurejo Kota Kediri. Analisa data yang digunakan adalah dengan uji regfresi linier.

\section{HASIL PENELITIAN}

Berikut ini adalah karakteristik Responden

Tabel 1 Karakteristik Responden

\begin{tabular}{|c|c|}
\hline \multicolumn{2}{|l|}{ Karakteristik } \\
\hline Usia: & \\
\hline a. Dewasa & 13 \\
\hline b. Lansia awal & 10 \\
\hline c. Lansia akhir & 7 \\
\hline
\end{tabular}

\begin{tabular}{lcc}
\hline Jenis Kelamin: & & \\
a. Laki-laki & 8 & 26 \\
b. Perempuan & 22 & 73
\end{tabular}

\begin{tabular}{lll}
\hline \multicolumn{2}{l}{ Pendidikan: } & \\
a. SD & 12 & 40 \\
b. SMP & 5 & 16 \\
c. SMA & 9 & 30 \\
d. PT & 4 & 13
\end{tabular}

\begin{tabular}{llcc}
\hline a. & Tidak bekerja & 14 & 46 \\
b. Wiraswasta & 10 & 33 \\
c. Swasta & 2 & 6 \\
d. & Buruh & 4 & 13
\end{tabular}

Penghasilan:

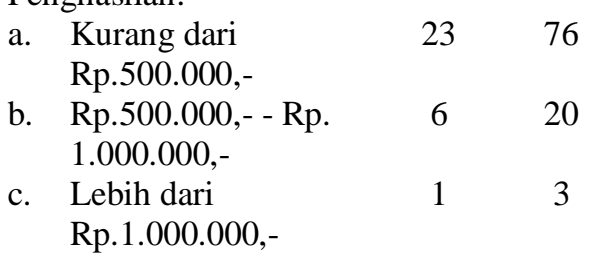

Status pernikahan:

$\begin{array}{llcc}\text { a. Belum menikah } & 4 & 13 \\ \text { b. Menikah } & 24 & 80 \\ \text { c. Janda/duda } & 2 & 6\end{array}$

Hubungan dengan pasien:

$\begin{array}{llcc}\text { a. } & \text { Orang tua } & 8 & 26 \\ \text { b. } & \text { Saudara kandung } & 9 & 30 \\ \text { c. Suami/istri } & 2 & 6 \\ \text { d. } & \text { Lainnya } & 11 & 36\end{array}$

\begin{tabular}{lcc}
\hline Lama sakit: & & \\
a. Kurang dari 1 tahun & 0 & 0 \\
b. 1-5 tahun & 13 & 44 \\
c. Lebih dari 5 tahun & 17 & 56
\end{tabular}

Nilai p-value pada hasil pengaruh beban terhadap stres adalah 0.008 (pvalue < 0.05). Jadi ada pengaruh yang signifikan pada beban terhadap stres yang dirasakan keluarga dalam merawat pasien gangguan jiwa.

\section{PEMBAHASAN}

Usia pada penelitian ini terbanyak adalah usia sebelum 55 tahun. Ini merupakan usia dewasa menengah (40-65 tahun) yaitu usia kemandirian dalam hidup, mencapai karir yang memuaskan, dan mencapai tanggung jawab penuh (Kozier, 2011). Tugas-tugas perkembangan ini merupakan suatu ideal diri yang menuntut responden mampu mencapainya, sehingga membuat responden harus berfikir keras untuk memenuhinya. Hal ini yang menjadikan suatu stresor atau beban pikiran bagi keluarga. 
Responden pada penelitian ini sebagian besar adalah perempuan. Seorang perempuan lebih banyak di rumah, sedangkan seorang laki-laki tugasnya mencari nafkah (keluar rumah), sehingga banyak care giver yang jenis kelaminnya adalah perempuan.

Care giver yang merawat ODGJ pasti mempunyai masalah (beban) baik yang tampak maupun tidak tampak. Ratarata beban yang dialami oleh responden adalah 39,92. Sebuah survey mengenai caregiver di keluarga menunjukkan bahwa beban yang paling besar dirasakan adalah mengkhawatirkan masa depan, berkurangnya konsentrasi, terganggunya rutinitas sehari-hari, merasa bersalah karena merasa apa yang dilakukan tidak cukup baik, merasa terperangkap di rumah, dan merasa sedih karena perubahan pada anggota keluarga (Rose et al., 2006 dalam Stuart, 2013).

Beban dapat bersifat subjektif atau objektif. Beban objektif terkait dengan perilaku klien, penampilan peran, efek luas pada keluarga, kebutuhan akan dukungan, dan biaya yang dikeluarkan karena penyakit. Beban subjektif adalah perasaan terbebani yang dirasakan oleh seseorang; bersifat individual dan tidak selalu berhubungan dengan bagian dari beban objektif. Pengkajian beban pada keluarga memungkinkan perawat mengetahui apakah keluarga butuh bantuan (Stuart, 2013). Beban yang tampak dirasakan oleh keluarga antara lain lelah dalam merawat pasien, lelah dalam keuangan yang harus mengeluarkan uang untuk biaya pasien, lelah fisik karena terus-terusan merawat pasien. Selain itu keluarga juga merasakan beban yang tidak nyata yaitu lelah secara emosional.

Selain beban, keluarga juga merasakan stres. Rata-rata stres yang dialami keluarga adalah 100.33. Stress adalah kondisi ketidakseimbangan yang terjadi saat ada kesenjangan keinginan individu dalam lingkungan internal atau eksternalnya dengan kemampuannya untuk menghadapi keinginan-keinginan tersebut (Townsend, 2009). Stresor adalah keinginan dari lingkungan internal atau eksternal individu yang meningkatkan respon fisiologis dan/atau psikologis seseorang. Kondisi klien dengan schizophrenia dapat menjadi stresor tersendiri bagi keluarga. Stres yang dialami antara lain stres secara fisik, pikiran dan emosi. Keluarga mengeluh stres fisik, yaitu terasa pegal-pegal di badan, tidur terganggu, keluhan lemas, keluhan pusing, dan keluhan fisik yang lain. Stres emosi yang dirasakan keluarga antara lain mudah marah, sedih, mudah tersinggung, malu bergaul malu karena adanya stigma negatif pada keluarga (adanya omongan-omongan yang negatif dari tetangga). Stres pikiran yang dirasakan keluarga antara lain bingung cara merawat pasien dan tidak tahu harus melakukan apa supaya keluarga segera sembuh.

\section{KESIMPULAN DAN SARAN}

Karakteristik keluarga yang merawat ODGJ usia terbanyak adalah lansia awal, jenis kelamin terbanyak perempuan, pendidikan SD, pekerjaan wiraswasta, penghasilan kurang dari Rp. 500.000,-, status pernikahan menikah, hubungan dengan pasien keluarga inti (orang tua dan saudara kandung), dan lama sakit lebih dari satu tahun.

Nilai p-value pada hasil pengaruh beban terhadap stres adalah 0.008 (pvalue < 0.05). Jadi ada pengaruh yang signifikan pada beban terhadap stres yang dirasakan keluarga dalam merawat pasien gangguan jiwa.

Hasil penelitian ini diharapkan dapat menjadi dasar untuk penelitian selanjutnya tentang beban dan stres, baik yang merawat pasein jiwa maupun pasien umumnya. Selain itu, penelitian ini diharapkan dapat menjadi dasar pengambilan kebijakan yang harus lebih memperhatikan bukan hanya pasien namun juga orang-orang yang ada disekitar pasien. 


\section{DAFTAR PUSTAKA}

Departemen Kesehatan Republik Indonesia. (2006). (RI, 2006) (Cetakan ke-18). Jakarta, Indonesia: Author.

$$
\text { (2012). Profil }
$$

Kesehatan Indonesia. Diakses dari http://www.bankdata.depkes.go.id/ nasional/public/report/createtablepi t tanggal 26 Mei 2013.

Dharma, K.K. (2012). Metodologi Penelitian Keperawatan., Panduan Melaksanakan dan Menerapkan Hasil Penelitian. Jakarta: CV Trans Info Media.

Dinas Kesehatan Kota Kediri. (2016). Laporan Data Kesehatan Jiwa di Kota Kediri.

Friedman, M.M. (2010). Buku Ajar Keperawatan Keluarga. Riset, Teori dan Praktik. Jakarta: EGC.

Gallin, J.I. \& Ognibene, F.P. (2007). Principles and Practice of Clinical Research. USA: Elsevier.

Hastono, S.P. \& Sabri, L. (2011). Statistik Kesehatan. Jakarta: PT Raja Grafindo Persada.

Hastono, S.P. (2007). Analisa Data Kesehatan. UI: FKM.

Loiselle, C.G. \& McGrath, J.P. (2011). Canadian Essentials of Nursing Research. Canada: Lippincott Williams \& Wilkins.

NANDA International. (2012). Diagnosis Keperawatan, Definisi dan Klasifikasi 2012-2014. Jakarta: EGC.
Practice. Philadelphia: Lippincitt Williams \& Wilkins.

Riduwan. (2010). Metode dan Teknik Menyusun Tesis. Bandung: Alfabeta.

Sekaran, U. \& Bougie R. (2011). Research Methods for Business. $5^{\text {th }}$ Ed. Britain: Wiley.

Stuart, G.W. (2013). Principles and Practice of Psychiatric Nursing. $10^{\text {th }}$ Ed. Canada: Evolve.

Townsend, M.C. (2009). Psychiatric Mental Health Nursing, Concepts of Care in Evidence-Based Practice. $6^{\text {th }}$ Ed. Philadelphia: Davis Plus.

Varcarolis, E.M. \& Halter, M.J. (2010). Psychiatric Mental Health Nursing, A Clinical Approach. $6^{\text {th }}$ Ed. Canada: Elsevier.

Videback, S.L. (2011). PsychiatricMental Health Nursing. $4^{\text {th }}$ Ed. China: Wolters Kluwer.

Polit, D.F. \& Beck, C.T. (2012). Nursing Research, Generating and Assessing Evidence for Nursing 